\title{
Management of iatrogenic injuries due to endoscopic sphincterotomy: Surgical or conservative approaches
}

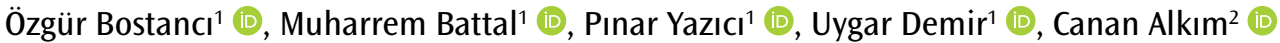

\section{ABSTRACT}

ORCID IDs of the authors:

Ö.B. 0000-0002-6336-0420

M.B. $0000-0002-5262-7177$

P.Y. $0000-0002-3445-5084$

U.D. 0000-0002-6869-5027

C.A. $0000-0002-8566-4521$

\section{Cite this paper as:}

Bostancı Ö, Battal M,

Yazıı P, Demir U, Alkım C

Management of iatrogenic

injuries due to endoscopic

sphincterotomy: Surgical or

conservative approaches. Turk

J Surg 2018; 34: 24-27.

'Department of General Surgery, Şişli Etfal Training and Research Hospital, İstanbul, Turkey

${ }^{2}$ Department of

Gastroenterology, Sişli Etfal

Training and Research Hospital, İstanbul, Turkey

This study was presented at the $12^{\text {th }}$ International Congress of the European-African HepatoPancreato-Biliary Association, $23^{\text {rd }}-26^{\text {th }}$ of May, 2017, Mainz, Germany.

Address for Correspondence Pinar Yazıcı e-mail: drpinaryazici@gmail.com

Received: 23.01.2017

Accepted: 20.04.2017

Available Online Date: 03.01.2018

(C) Copyright 2018

by Turkish Surgical Association
Objective: The best therapeutic approach for endoscopic retrograde cholangiopancreatography-related perforations remains controversial; while some authors suggest routine conservative management, others advocate mandatory surgical exploration. We aimed to evaluate our clinical experience of perforations during endoscopic sphincterotomy.

Material and Methods: A retrospective chart review from January 2010 to October 2015 identified 20 patients with endoscopic retrograde cholangiopancreatography-related perforations. Data collection included demographics, time to diagnosis, type of perforation, treatment strategy, surgical procedure, complications, hospital stay, and outcome. All patients were classified into two groups on the basis of radiological and operative findings.

Results: Only five patients underwent surgical treatment, whereas 15 patients were managed conservatively. The mean time to diagnosis was $7.8 \mathrm{hrs}$ (range: 1 to $36 \mathrm{hrs}$ ). In patients who underwent surgical treatment, the types of perforations included type I and III in one patient each and type II in three patients. Surgical procedures included laparoscopic and open cholecystectomy with t-tube drainage in two patients each and primary repair of duodenal injury with hepaticojejunostomy in one patient. Among conservatively managed patients, eight, four, and three had type II, type III, and type IV injuries, respectively. Of these 15 patients, $60 \%(n=9)$ underwent percutaneous procedures. The mean length of hospital stay was similar for conservatively and surgically treated patients (12 vs. 12.4 days, respectively, $\mathrm{p}=0.790)$. One patient $(5 \%)$ with type I injury died of multiorgan deficiency.

Conclusion: With close close clinical follow-up, medical treatment can be beneficial for most patients, and surgical procedures should be reserved for patients with type I (definite) and type II/III injuries; in patients with these clinical parameters, conservative management will likely be unsuccessful.

Keywords: Complication, duodenum perforation, endoscopic retrograde cholangiopancreatography, surgical repair

\section{INTRODUCTION}

Endoscopic retrograde cholangiopancreatography (ERCP) was first described in 1968 by McCune et al. (1). It is an invasive method used today for the diagnosis and treatment of pancreatic and biliary diseases. Since the emergence of other non-invasive or less invasive methods, such as magnetic resonance colangiopancreatography (MRCP) and endoscopic ultrasonography (EUS), respectively, ERCP has been used mainly for treatment (2). This highly invasive procedure is associated with a higher frequency of serious complications, ranging between $4 \%$ and $16 \%$ (3-7). Although the risk of ERCP-related perforation (ERCP-rP) is low ( $<1 \%$ for patients undergoing sphincterotomy), it is associated with high morbidity and mortality, particularly for patients in whom conservative therapy is unsuccessful and who have a delayed diagnosis of perforation (8-11).

There is still no consensus on whether ERCP-rP should be managed by a conservative or surgical approach. Literature related to the management of ERCP-related complications mostly includes limited case series and case reports (12-14). Although in the past, many authors advocated early surgical management for ERCP-rP, most recent studies have reported good outcomes with conservative management for carefully selected patients $(5,15)$. Early diagnosis and definition of injury type play major roles in the management of ERCP-rP. Increased experience in endoscopic interventions and emerging technology has enabled clinicians to address these injuries with endoscopic interventional methods. Retroperitoneal perforation related to papillotomy is observed in most patients; intraperitoneal perforation is observed less frequently.

Based on a single center experience with the management of ERCP-rP, we aimed to analyze the types of injuries, surgical options, and outcomes of patients with ERCP-rP.

\section{MATERIAL AND METHODS}

Over a five-year period between January 2010 and October 2015, all ERCP procedures $(n=3432)$ that were performed at the Gastroenterology and General Surgery Clinic at Şişli Hamidiye Etfal Training and Research 
Hospital were retrospectively reviewed. The 17 patients with a diagnosis of ERCP-rP were enrolled in the study. This study was approved by the institutional review board at our institution (Local Ethics Committee of Şişli Hamidiye Etfal Training and Research Hospital), and informed written consent was obtained from all the reviewed subjects to use their clinical records in this study. The ERCP reports and medical records of the patients with perforations were evaluated. While 13 patients $(0.3 \%)$ were from our hospital, 4 cases were referred from different hospitals. All patients were classified classified into two groups based on treatment approaches: conservative $(C)$ and surgical $(S)$.

All patients underwent chest X-rays, plain abdominal radiography, abdominal ultrasound (US), and computed abdominal tomography (CAT). Complete blood counts and biochemical profiles were assessed. Data collection included demographic features, indication for ERCP, type of injury, time to diagnosis, treatment approach (conservative or surgery), surgical procedure, length of hospital stay, morbidity and mortality.

The classification of ERCP-rP is shown in Table 1. Based on the type of injury, patients with type I injury underwent surgical treatment, while conservative treatment was mostly preferred for patients with type II, III, and IV injuries. Patients treated with a conservative approach underwent closed monitoring for vital signs, intermittent physical examination, and blood tests. In the presence of at least two of systemic inflammatory response syndrome (SIRS) criteria (sepsis) (10) (body temperature $>38^{\circ} \mathrm{C}$ or $<36^{\circ} \mathrm{C}$, heart rate $>90$ pulse/min., respiratory rate $>20 /$ min. or $\mathrm{PaCO}_{2}<32 \mathrm{mmHg}$, white blood cell count $>12000 /$ $\mathrm{mm}^{3}$ or $<4000 / \mathrm{mm}^{3},>10 \%$ immature neutrophil (bands)), repeat CAT was performed to determine possible free fluid collection or abscess formation. Percutaneous abscess drainage was applied for patients with conservative treatment whose CAT scans revealed intraperitoneal or retroperitoneal localized abscesses during the follow-up period.

For statistical analysis, Statistical Package for the Social Sciences version 20.0 for (IBM Corp.; Armonk, NY, USA) was used. Only descriptive measures were used. Continuous variables were represented as mean \pm standard deviation or median and range. Categorical variables were represented as percentages.

\section{RESULTS}

Of the 3492 ERCP cases during the study period, 59 patients with abdominal pain following ERCP procedures were admitted to the General Surgery Clinic with a preliminary diagnosis of ERCP-rP. Free air in the intraperitoneal and/or retroperitoneal areas, contrast leakage, fever and/or elevated leucocytes, and C-reactive protein were found in 16 patients; they were

Table 1. Classification of ERCP-related perforations

\section{Type of injury Definition}

\begin{tabular}{|ll|}
\hline I & Lateral or medial wall perforations \\
\hline II & Perivaterian injuries \\
\hline III & $\begin{array}{l}\text { Distal bile duct injuries related to wire or basket } \\
\text { instrumentation near an obstructing entity }\end{array}$ \\
\hline IV & Retroperitoneal air alone \\
\hline ERCP: endoscopic retrograde cholangiopancreatography
\end{tabular}

diagnosed with post-ERCP iatrogenic duodenal perforation $(0.4 \%)$. In addition, four patients with a diagnosis of ERCP-rP were referred from other hospitals. Only 3 out of 20 patients were diagnosed with perforation due to contrast leakage during $\mathrm{ERCP}$, whereas the remaining patients (85\%) were diagnosed during post-ERCP follow-up.

There were 12 female (60\%) and 8 male (40\%) patients with a mean age of 46 years (range: 23 to 76 ). The mean time to diagnosis was 7.8 hours (range: 1 to 36 hours). In patients with a suspected perforation, oral intake was ceased and initial treatment with fluids, analgesia and appropriate antibiotics was started. Three patients (17\%) initially treated with a conservative approach underwent surgical procedures due to peritonitis findings, fever, and elevated WBC and C-reactive protein during follow-up. The mean duration between diagnosis and surgery was 24 hours (range: 18 to 36 ).

The mean length of hospital stay was 12 days in the conservative group, whereas it was 12.4 days for the surgery group. In nine patients with conservative treatment (Table 2), percutaneous drainage was performed during follow-up due to intraabdominal abscess. One patient in the surgery group died of sepsis on postoperative day 8 . She was diagnosed with perforation 12 hours after ERCP and underwent hepaticojejunostomy with gastroenterostomy. Detailed data for the patients treated with surgical approaches are shown in Table 3.

\section{DISCUSSION}

Although ERCP is an invasive procedure, it is still one of the most common procedures used for the diagnosis and

Table 2. Demographics and diagnosis of patients who were not surgically treated

\begin{tabular}{|c|c|c|c|c|c|}
\hline Age & Sex & $\begin{array}{l}\text { Indication } \\
\text { for ERCP }\end{array}$ & $\begin{array}{c}\text { Type of } \\
\text { injury }\end{array}$ & $\begin{array}{l}\text { Time to } \\
\text { diagnosis } \\
\text { (hours) }\end{array}$ & $\begin{array}{l}\text { Length of } \\
\text { hospital } \\
\text { stay (days) }\end{array}$ \\
\hline 54 & M & $\mathrm{CL}$ & II & 2 & 7 \\
\hline 46 & $M$ & $\mathrm{CL}$ & IV & 3 & 9 \\
\hline 66 & $\mathrm{~F}$ & $\begin{array}{l}\text { Periampullary } \\
\text { tumor }\end{array}$ & ॥ & 1 & 12 \\
\hline 38 & M & $\mathrm{CL}$ & III & 1 & 10 \\
\hline 47 & $\mathrm{~F}$ & Cholangitis & II & 2 & 15 \\
\hline 43 & $\mathrm{~F}$ & $\mathrm{CL}$ & II & 13 & 35 \\
\hline 52 & $\mathrm{~F}$ & $\mathrm{CL}$ & III & 12 & 26 \\
\hline 71 & M & Pancreas tumor & II & 3 & 13 \\
\hline 33 & M & $\mathrm{CL}$ & III & 1 & 7 \\
\hline 58 & M & $\mathrm{CL}$ & II & 3 & 6 \\
\hline 45 & $\mathrm{~F}$ & $\mathrm{CL}$ & III & 8 & 12 \\
\hline 39 & $\mathrm{~F}$ & $\mathrm{CL}$ & IV & 1 & 7 \\
\hline 24 & $\mathrm{~F}$ & Cholangitis & II & 8 & 9 \\
\hline 23 & $\mathrm{~F}$ & Cholangitis & II & 2 & 8 \\
\hline 32 & $\mathrm{~F}$ & $\mathrm{CL}$ & II & 3 & 9 \\
\hline
\end{tabular}

M: male; F: female; CL: choledocholithiasis; ERCP: endoscopic retrograde cholangiopancreatography 
Table 3. Detailed data of patients who underwent surgical treatment

\begin{tabular}{|cccccc|}
\hline Age Sex & $\begin{array}{c}\text { Indication } \\
\text { for ERCP }\end{array}$ & $\begin{array}{c}\text { Type of } \\
\text { injury }\end{array}$ & $\begin{array}{c}\text { Surgical } \\
\text { procedure }\end{array}$ & $\begin{array}{c}\text { Time of } \\
\text { diagnosis } \\
\text { (hours) }\end{array}$ & $\begin{array}{c}\text { Length of } \\
\text { hospital } \\
\text { stay (days) }\end{array}$ \\
\hline $76^{*}$ & F $\begin{array}{c}\text { Choledochal } \\
\text { cyst (type 1) }\end{array}$ & I & $\begin{array}{c}\text { Primary repair } \\
\text { of injury+HJ+ } \\
\text { gastroenterostomy }\end{array}$ & 12 & 8 \\
\hline 43 & M & CL & II $\begin{array}{c}\text { Lap. chol+ } \\
\text { exploration of } \\
\text { CBD+T-tube } \\
\text { drainage }\end{array}$ & 7 \\
\hline
\end{tabular}

\begin{tabular}{ccccccc}
52 & F & Cholangitis & III & T-tube drainage & 24 & 13 \\
\hline 45 & $\mathrm{~F}$ & $\mathrm{CL}$ & II & Lap. chol+drainage & 18 & 12 \\
38 & $\mathrm{M}$ & $\mathrm{CL}$ & $\begin{array}{c}\text { II Cholecystectomy+ } \\
\text { exploration of } \\
\text { CBD+T-tube } \\
\text { drainage }\end{array}$ & 15 \\
\hline
\end{tabular}

M: male; F: female; CL: cholodocholithiasis; HJ: hepaticojejunostomy; CBD: common bile duct; Lap. chol: laparoscopic cholecystectomy

*This patient died of multiorgan failure

treatment of biliary diseases (1). It has various complications, including gastrointestinal system perforation, which has significant morbidity and mortality rates $(3-7,9)$. In this study, we evaluated the treatment approach to perforations and discovered that only some of these patients required surgical treatment. For better outcomes, diagnosis of the injury and determination of the injury type should be given priority.

While almost all authors advocate surgical treatment for type I injuries, a debate remains as to whether conservative or surgical strategy should be performed for other types of injuries. Timely diagnosis of ERCP-related perforations is important in establishing better treatment approaches. In cases of perforations involving peritoneal signs, type IV perforations are more commonly diagnosed. In contrast, it is more difficult to detect retroperitoneal perforations, which only can be identified using radiological imaging methods due to postERCP abdominal pain. Clinical studies investigating the diagnostic methods for ERCP-related perforations have revealed that CAT is the most sensitive method in patients with high suspicion of perforation (16). Genzlinger et al. (17) reported the efficacy of CAT after ERCP. About one-third of the patients with perforation are diagnosed at the time of ERCP procedure. In our study, diagnosis of perforation was established for only three patients (15\%) due to contrast leakage during ERCP. The remaining 17 patients were diagnosed using imaging methods (CAT, US, MRCP).

Various classification methods have been presented for the definition and classification of ERCP-related perforations (10, $11)$. In this study, we used the classification system that Stapfer et al. (10) previously introduced. They reported that type I injuries generally require extensive emergency surgical procedures, whereas type II and III injuries with minimal contrast leakage and absence of fluid accumulation can be managed conservatively. Type IV injuries are classified as pseudoperforations related to air pressure during ERCP.
There has been no consensus on the management of ERCPrelated gastrointestinal system perforations to date. Although emergency surgical treatment has been advocated in previous studies, conservative treatment was commonly reported with successful outcomes in appropriate cases in recent series. $(10,12,18,19)$. Mortality rates between $7 \%$ and $25 \%$ were reported in several studies, in which the most common types of perforations were type I and II $(12,19,20)$. In our study, the most common type was type II injury (60\%); only one patient with type I injury (5\%) died of sepsis.

Conservative treatments include endoscopic clip application and percutaneous drainage catheter insertion. Patients diagnosed with retroperitoneal abscess can be managed with percutaneous drainage, which may result in fistula formation. In our study, $60 \%$ (9 of 15) patients were managed conservatively by insertion of a percutaneous drainage catheter. Five of these patients required catheter adjustments or additional catheter insertion.

\section{CONCLUSION}

Accurate diagnosis and timely intervention are very important in patients with ERCP-rP. Clinical symptoms, imaging methods, and the mechanism of injury should be evaluated, and all these parameters should be considered before deciding whether to operate. Conservative treatment with close followup can prevent unnecessary surgery, whereas early operation on patients who fail to respond to medical treatment may prevent morbidity and mortality that can be caused by delayed surgery.

Ethics Committee Approval: Ethics committee approval was received for this study from the ethics committee of Şişli Hamidiye Etfal Training and Research Hospital.

Informed Consent: Written informed consent was obtained from patients who participated in this study.

Peer-review: Externally peer-reviewed.

Author Contributions: Concept - M.B. O.B., P.Y.; Design - O.B., P.Y., M.B.; Supervision - M.B., C.A., U.D.; Resource - P.Y., U.D., O.B.; Materials - P.Y., C.A., O.B.; Data Collection and/or Processing - P.Y., U.D., C.A.; Analysis and/or Interpretation - P.Y., O.B., C.A.; Literature Search - P.Y., O.B., M.B.; Writing Manuscript - O.B., M.B., P.Y.; Critical Reviews - C.A., M.B., O.B.

Conflict of Interest: No conflict of interest was declared by the authors.

Financial Disclosure: The authors declared that this study has received no financial support.

\section{REFERENCES}

1. McCune WS, Shorb PE, Moscovitz H. Endoscopic cannulation of the ampulla of vater: a preliminary report. Ann Surg 1968; 167: 752-756. [CrossRef]

2. Freeman ML, Nelson DB, Sherman S, Haber GB, Herman ME, Dorsher PJ, et al. Complications of endoscopic biliary sphincterotomy. New Engl J Med 1996; 335: 909-918. [CrossRef]

3. Silviera ML, Seamon MJ, Porshinsky B, Prosciak MP, Doraiswamy VA, Wang CF, et al. Complications related to endoscopic retrograde cholangiopancreatography: a comprehensive clinical review. J Gastrointestin Liver Dis 2009; 18: 73-82.

4. Lai CH, Lau WY. Management of endoscopic retrograde cholangiopancreatography-related perforation. Surgeon 2008; 6:45-48. [CrossRef] 
5. Freeman ML. Adverse outcomes of endoscopic retrograde cholangiopancreatography: avoidance and management. Gastrointest Endosc Clin N Am 2003; 13: 775-798. [CrossRef]

6. Loperfido S, Angelini G, Benedetti G, Chilovi F, Costan F, De Berardinis $F$, et al. Major early complications from diagnostic and therapeutic ERCP: a prospective multicenter study. Gastrointest Endosc 1998; 48: 1-10. [CrossRef]

7. Cotton PB, Garrow DA, Gallagher J, Romagnuolo J. Risk factors for complications after ERCP: a multivariate analysis of 11,497 procedures over 12 years. Gastrointest Endosc 2009; 70: 80-88. [CrossRef]

8. Scarlett PY, Falk GL. The management of perforation of the duodenum following endoscopic sphincterotomy: a proposal for selective therapy. ANZ J Surg 1994; 64: 843-846. [CrossRef]

9. Cho KB. The management of endoscopicretrogradecholangiopancreatography-relatedduodenalperforation. Clin Endosc 2014; 47: 341-345. [CrossRef]

10. Stapfer M, Selby RR, Stain SC, Katkhouda N, Parekh D, Jabbour $\mathrm{N}$, et al. Management of duodenal perforation after endoscopic retrograde cholangiopancreatography and sphincterotomy. Ann Surg 2000; 232: 191-198. [CrossRef]

11. Howard TJ, Tan T, Lehman GA, Sherman S, Madura JA, Fogel E, et al. Classification and management of perforations complicating endoscopic sphincterotomy. Surgery 1999; 126: 658-663. [CrossRef]

12. Koc B, Bircan HY, Adas G, Kemik O, Akcakaya A, Yavuz A, Karahan S. Complications following endoscopic retrograde cholangiopancreatography: minimal invasive surgical recommendations. PLoSOne 2014; 26: e113073. [CrossRef]

13. Kodali S, Mönkemüller K, Kim H, Ramesh J, Trevino J, Varadarajulu
$\mathrm{S}$, et al. ERCP-related perforations in the new millennium: A large tertiary referral center 10-year experience. United European Gastroenterol J 2015; 3: 25-30. [CrossRef]

14. Kirtane T, Singhal S. Endoscopic closure of iatrogenic duodenal perforation when using dual over-the-scope clips. Gastrointest Endosc 2015; pii: S0016-5107(15)02748-0.

15. Enns R, Eloubeidi MA, Mergener K, Jowell PS, Branch MS, Pappas TM, et al. ERCP-related perforations: risk factors and management. Endoscopy 2002; 34: 293-298. [CrossRef]

16. de Vries JH, Duijm LE, Dekker W, Guit GL, Ferwerda J, Scholten ET. CT before and after ERCP: detection of pancreatic pseudotumor, asymptomatic retroperitoneal perforation, and duodenal diverticulum. Gastrointest Endosc 1997; 45: 231. [CrossRef]

17. Genzlinger JL, McPhee MS, Fisher JK, Jacob KM, Helzberg JH. Significance of retroperitoneal air after endoscopic retrograde cholangiopancreatography with sphincterotomy. Am J Gastroenterol 1999; 94: 1267-1270. [CrossRef]

18. Knudson K, Raeburn CD, Mclntyre RC Jr, Shah RJ, Chen YK, Brown $W R$, et al. Management of duodenal and pancreatico biliary perforations associated with periampullary endoscopic procedures. Am J Surg 2008; 196: 975-981. [CrossRef]

19. Rabie ME, Mir NH, Al Skaini MS, El Hakeem I, Hadad A, Ageely H, et al. Operative and non-operative management of endoscopic retrograde cholangiopancreatography-associated duodenal injuries. Ann R Coll Surg Engl 2013; 95: 285-290. [CrossRef]

20. Miller R, Zbar A, Klein Y, Buyeviz V, Melzer E, Mosenkis BN, et al. Perforations following endoscopic retrograde cholangiopancreatography: a single institution experience and surgical recommendations. Am J Surg 2013; 206: 180-186. [CrossRef] 